\title{
Agrarian Structure Transformation and Rural Development in Russia: a Scientific Review
}

\author{
Tiutiunikov A.A.* \\ Scientific Research Institute of Agroindustry Complex \\ Economics and Organization in the Central Black Earth \\ Region \\ Voronezh, Russia \\ e-mail: niieoapk@mail.ru \\ Pechenevsky V.F. \\ Scientific Research Institute of Agroindustry Complex \\ Economics and Organization in the Central Black Earth \\ Region \\ Voronezh, Russia \\ e-mail: niieoapk@mail.ru
}

\author{
Chernysheva I.I. \\ Scientific Research Institute of Agroindustry Complex \\ Economics and Organization in the Central Black Earth \\ Region \\ Voronezh, Russia \\ e-mail: niieoapk@mail.ru \\ Zakshevskii G.V. \\ Scientific Research Institute of Agroindustry Complex \\ Economics and Organization in the Central Black Earth \\ Region \\ Voronezh, Russia \\ e-mail: niieoapk@mail.ru
}

\begin{abstract}
The regional rural development model of Russia, which is the agrarian structure transformation result, is in conflict with the real interests of a significant part of the rural population and rural producers. There is a predominance of two opposite farms classes: large integrated industrial-type enterprises, on the one hand, and household plots, on the other, while independent agricultural enterprises and farmers are limited in their development potential realizing. The observed imbalances contribute to maintaining a high depression level in the rural economy and rural communities. It seems challenging to the problem of finding directions for the agrarian structure transformation, focused on increasing the potential using efficiency of rural development and smoothing contradictions between the agrarian relations subjects and balancing their economic interests.
\end{abstract}

Keywords - agrarian structure, agrarian structure transformation, rural development, rural economy disproportions, agrarian policies.

\section{INTRODUCTION}

The currently existing mixed economy model of rural development in the Russian Federation is the result of the revolutionary changes of the economic paradigm of the agrarian sector that has been implemented in our country throughout the past century. It is based on the parallel operation of four main economical modes: large-size agricultural holdings of the vertical type, employee-owned enterprises, both farm and private households based on different types of economy (market system, distributing system and reciprocal system). The competition between the paradigm results in a high level of uncertainty and risks in the agrarian economy, contributes to the archaization and disintegration of rural communities, complicates the process of adaptation of the rural population to the new economic conditions. One of the specific features is the significant regional differences considering the stages of rural development. From there, rural areas having reached the maturity of socio-economic development can coexist with rural areas of the marginal type.

The problems concerning the development of agriculture and rural areas are state-recognized in the Russian Federation, as evidenced by the State program for the development of agriculture and regulation of agricultural products, raw materials and food markets for 2013-2020, the Concept of sustainable development of rural territories of the Russian Federation for the period until 2020, the Federal target program "Sustainable development of rural territories for 2014-2017 and for the period until 2020", the Strategy for sustainable development of rural territories of the Russian Federation for the period until 2030. The goals, objectives and measures of state support set out in the programs make it possible to establish the fundamental features of the state-run paradigm of rural development, namely: agricultural production buildup while primarily supporting the corporate sector of agricultural production, increasing the export orientation of the agri-food complex, reducing the import dependence of the domestic food market, improving social infrastructure of rural areas, stabilization of rural population and labor forces. At the same time, the rural development paradigm proposed by the Government is the subject of scientific discussions in recent economic studies concerning the problems of development, functioning and transformation of agrarian structures at the state and regional levels.

\section{CRitical Analysis \& Evaluation}

The scientific notion "agrarian structure" became firmly established in economic terminology in the second half of the 20th century. In spite the single elements defining this concept have been deeply studied long before that. In 1951, the agrarian structure was defined in the report of the UN Department of Economic Affairs [1] as a set of institutional framework for agricultural production, including: the landtenure system; land distribution among farms of different sizes 
and different forms of ownership; income distribution to owners and land users; industrial, marketing and lending management; agricultural financing arrangements; taxation system of agricultural commodity producer and rural sector; management system of soft infrastructure in rural areas. Several researches on developing countries reveal a number of defects in the agrarian structure which were identified as the most serious drag on the economic growth.

Currently, an in-depth study of the specifics of the agrarian structure, the directions and possibilities of its transformation is carried out mainly on countries and regions that produce a shift to capitalist economy in agriculture as a result of dismantling traditional, postcolonial, socialist and communist systems. The studies of agrarian structures of Eastern European countries are of a great practical concern [2-11], which were formed against the background of institutional changes similar to Russian: privatization of state land and capital in agriculture, accelerated transition to exchange relations, fundamental reduction of state support to the agricultural sector, etc. For example, D. Walczak and M. Pietrzak [2], examining data on the regions of Poland from 1921 to 2002 using the methods of spatial econometrics, found out that the differentiation of the agrarian structure in this country is long-term and sustainable, in spite of a number of fundamental changes in agriculture. It is assumed that the formation of the agrarian structure is subject to spatial, economic, social and historical factors, which determine the need for the geographically differentiated agricultural policies development in the future. P. Otiman [3] researching into the modern agrarian structure of Romania has concluded that the undue subdivision of land tenure system resulted in the underutilization of the economic potential of the country's agricultural sector. At the same time, he outlines that the development of sizeable enterprises in certain regions leads to an increase in rural poverty.

The modern agrarian structure in Russia was the result of the mixed economy that took shape in agriculture as a result of reforms of the 90 s. It was preceded by the actual destruction of large-scale production in the form of a collective-state farm system with an extremely weak manifestation of its new forms. The research of V. Bashmachnikov, N. Buzdalov, A. Petrikov, A. Trafimov, V. Uzun, N. Filimonov and other authors. Having studied a number of different interpretations of the term "agricultural structure" set out in these works, it is possible to work out the most general definition, i.e. the ratio of agricultural groups of farms and their share in the total cost of production, land area and farm production. At the same time, various approaches are offered to identify farm groups for classifying agricultural commodity producers, determining the quantity and the cost of goods produced, etc. It is noted that the system of classification of commodity producers used by the Russian statistical data producers based on three categories of farms and types of legal entity (agricultural enterprises, farms and households) does not take into account the significant resource and economic characters. Therefore, they are not suggested to be used for the cross-country and regional comparisons. Classifications are widespread in international practice: by revenue from sales of agricultural products (USA), standardized gross income (EU), as well as other significant features - area, population, specialization, role in employment and family income; therefore, they are insufficient for an adequate comparison of agricultural structures not only at the intercountry, but also at the regional level. The economy class, as a rule, combines farms that are allocated mainly on one basis - for example, by the size of revenue or by the size of land use; type - households that combine several features. It would be more appropriate to divide households into economic classes (according to one economic characteristic) or types (combining several characteristics). Most of the methodologies for the classification of regional agrarian structures are based on pointing out the farm groups that have similar set of characteristics of economic essence and size according to the share in the farm production [12-22].

Having examined the results of the post-Soviet transformation of the agricultural sector in Russia, V. Uzun [12] conditionally identified three types of agricultural structures at the regional level: corporate (with a share of agricultural enterprises in gross output of more than $50 \%$ ), mixed (30-50\%) and family (less than 30\%). The most important factors that influenced the differentiation of the agrarian structures of the regions are natural conditions; land security; ethnographic factor; corporate farms efficiency; regional agrarian policy. The worst indicators of natural and land factors, the low level of regional support for large commodity forms, as well as the high proportion of national minorities in the population of the regions lead to a tendency to form a family agrarian structure. Developing Uzun's ideas V. Bogdanovsky identifies the family, family-corporate, corporate-family and corporate types of agricultural structure, analyzing the differences in the shares of agricultural production, including within the small business sector [13]. However, the problem with these typologies is that their subjects are not a direct reflection of their economic nature, because all of them can be of any size and reflect any integration into social production. Therefore, agrarian structures representing the economic classes of farms seem more objective for such an analysis.

For example, a typology of agricultural structures, based on the following economic classes: "...residential, recreational, consumer, utility, subsidiary family, commodity family, commodity of the capitalist and large-size capitalist economy" is proposed in the studies conducted in 2011-2015 by Russian Institute of Agrarian Problems and Informatics. According to the criterion of prevalence in the standardized revenue share of farms of a particular class... the following types of territorial agricultural structures are pointed out: subsistence sector, family commercial farming, areas of capitalist agriculture, and areas of large-size capitalist economy and areas with mixed agricultural structure. [14] In some sources, this typology is also supplemented by areas of agricultural desolation, where there is less than $50 \%$ of agricultural land is used. Almost all researchers of this issue note a significant extension of the Russian agrarian structure differentiation in the 1990-2010s, due to the transformation of the agricultural economy. It reveals a geographical type of agrarian structure that can be traced at both levels federal and regional, due to a combination of interacting factors: natural, social, spatial and economic [15]. 
The study of the factor influence degree on the agricultural structure type formation in the region is presented in the work of S. Siptits and E. Gataulina [15], where a correlation and regression analysis of the four classes' proportions of commodity farms in the standardized revenue of agricultural production in each of the regions of Russia was carried out. Natural (bioclimatic potential of the region), social (urban to rural population ratio, migration growth rate, percentage of Russian population in the region), economic (profitability of agriculture without subsidies, provision of the rural population with arable land, the volume of regional support for rural areas were selected as significant influencing factors) farms) and spatial (the presence of the sea border, the presence of state borders in the north, south, west and east of the region).

The structures characterized by a significant role of small parcel-structural family farming dominate in the lowurbanized regions with a considerable share of the nonRussian population. Agricultural structures with a predominance of the capitalist system are characterized by high land availability, the negative demographic balance and the worst bioclimatic conditions (the "old industrial" and northern regions of the European part of Russia). The formation of agrarian structures with a significant share of large-size integrated farms is observed in the regions located in the European part of Russia, which lean toward large urban centers and are characterized by low land availability and the relative profitability of agricultural production.

The comparative analysis of the agrarian structures shows that the bulk of agricultural production falls to the share of large-size farms of commercial type in most developed countries, attracting the necessary minimum of hired labor [16]. Small and medium-size farms participate in separate cycles of integration production, produce healthy nutrition, local food and organic agricultural products, and small parcelstructural farms have subsidiary and social significance. Such a model of the agricultural structure seems to be most effective in conditions of laborsaving agriculture: labor productivity and land use efficiency are consistently increasing from class to class, up to large commodity commercial farms that produce the bulk of products for food corporations. The efficiency of the use of labor, land and capital in such a structure increases with the consolidation of class objects, which indicates its adequacy to the law of scale of production. On the contrary, the agrarian structure as a whole in Russia seems bipolar, with a predominance of two classes. The first class includes smallscale capitalist farms with high land availability, based on the principles of over-concentration of resources and management, which provide about $60 \%$ of the standardized revenue of the agricultural sector. Unlike the United States, the vast majority of large agricultural producers belong to the corporate sector, which is characterized by a mismatch of owners, managers and workers circles, resources overconcentration and the formation of large hierarchical management structures. It is easier for such enterprises to adapt to the peculiarities of the business environment existing in Russia; however, it is they who preserve the gap behind countries with a developed farming sector. The second class consists of about 30 million of small-scale producers, whose primary activities are characterized by self-exploitation and excessive investment of labor (35\% of standardized revenue). This indicates that business and the state are not completely coping with the task of providing food and maintaining the standard of living. The land unit output in subsidiary and recreational farms is the highest among all, while labor productivity is the lowest, which is more consistent with countries with a land-saving native model of agricultural development (Japan, China, Vietnam, etc.). It was argued [17] that such an agrarian structure catalyzes negative phenomena in the sphere of employment and incomes of the rural population, and prevents the lagging behind countries with the developed farming sector. A high level of negative correlation (negative - with the level of employment and income, positive - with unemployment) is typical for regions with a high share of households, which indicates their negative role in the industry's movement towards an effective employment structure.

It is assumed that the disproportionate agrarian structure in Russia is conserved as a result of the concentration of state support in the large-size corporate sector of agriculture. Recipients of large subsidies are physically unable to ensure agricultural production throughout the country due to a number of natural and economic constraints [12]. Therefore, the state policy of "supporting the strong" restrains the modernization of many smaller farms and contributes to the growth of seeds of agricultural development, which leads to stagnation of small and medium-size agricultural producers. The observed polarization of the agrarian structures has a negative impact on the sustainability of agriculture and rural areas: the agricultural sector loses the multiplier function of the rural economy; the principle of equal access of agricultural producers to the resources is not ensured; the occurred superconcentration of production results negatively in the environment and the quality of life of rural communities; the underdevelopment of the farming sector weakens the process of forming a middle class of rural residents.

E. Ivanova notes [18] that the alternative to the agrarian structure that is emerging in our country, characterized by discrimination and intense competition between the various economic classes of agricultural commodity producers, could be the cooperation of rural economic structures based on the territorial division of labor across the entire national economy. Two possible vectors of agro-industrial complex reintegration are proposed: 1) on the basis of the concept of "new consumer cooperation" - the institutional design of macro-hierarchical structures of the cooperative type, combining the most diverse economic forms; 2) based on the clustering policy of the agroindustrial complex, within the framework of which conditions are created for self-organization of cluster-type network structures characterized by the unity of competition and cooperation of economic entities. In practice, cooperative and cluster structures are formed not just in parallel, but in the unity of the internal logic of their development. On the ground, cooperatives are typical actors of clustering, and cluster networks and cooperative structures are hybrid forms of business organization.

From the point of view of a number of researchers, improving the agricultural structure in Russia is possible by reducing the polarization of production in the extreme groups 
of extremely small and large agricultural producers. To achieve this goal, V. Shagayda proposes [19] the creation of incentives for the application of appropriate management practices for small producers, which will facilitate the transfer of a significant part of production from the low-commodity sector to the farm sector. Organizational and institutional changes in agricultural policy should be carried out in the following areas: ensuring equal access to state support in order to increase the coverage of agricultural producers, modernization and reduce the focus of agricultural development; simplification of the mechanism for assigning subsidies and reducing the level of differentiation; restriction of state support per organization, owner or affiliation in order to prevent overconcentration of production and capital; providing grant support to households to create new industries, in order to stimulate the transition to the farmer level.

According to E.A. Gataulina [16], the state should intensify efforts to "grow" farmers, and especially to create a favorable institutional environment - cooperation, information and advisory services, accessible service organizations. In the process of land reform, the lands of collective and state agricultural enterprises were transferred to their workers and some other categories of rural residents (pensioners, teachers, doctors, etc.) and the government hoped that a new form of agribusiness for the Russian economy - farming - would emerge and spread widely. However, none of the reformers took into account that in developed countries, farming evolved slowly and gradually, in conjunction with the infrastructure and business environment. However, even such a crude implementation of a business form without adopting the appropriate institutions was not completely a failure, as farms appeared and survived, formed their own segment, which has a sufficiently high proportion in certain types of agricultural products.

V. Uzun [20] proposes to carry out in-depth differentiation of state support for agriculture, which is based on the principle of support mechanisms conformity to the class of farms. Support mechanisms for large farms may include detailed procedures for the allocation and control of the use of budgetary funds by officials of the agricultural administration. It is impossible to exercise the same control over small forms of management; therefore, for these classes of households, simplified procedures are necessary with the possible transfer of some control functions to agricultural credit and consumer cooperatives. When developing federal and regional agrarian policies, it is necessary to take into account the whole variety of agrarian structures of the constituent entities of the Russian Federation and administrative regions in order to ensure access to state support not only to entities and areas with large capitalist agriculture, but also to territories where small agricultural business predominates. It is also required to provide for special measures in the framework of the development policies of the regions of agricultural neglect.

At the same time, S. Siptits doubts that the simultaneous implementation of state support for small and large agricultural businesses will contribute to their harmonious development. The matrix of pairwise correlation of the standardized revenues shares of various agricultural producers' classes showed that various types' actors, as a rule, could not cohabit well in the territorial agricultural structure [15]. Only classes of subsidiary farms and commodity farms are positively correlated with each other, and large capitalist farms tend to supplant all other forms.

More balanced is the opinion of V. Bogdanovsky [13], who believes that the subsequent development of the agricultural structure in Russia will consist in optimizing the ratio between the agricultural sectors in terms of the economic and social efficiency of their production, taking into account the characteristics of the resource base and other conditions of the regions, up to national. It should be assumed that for the time being there remains great relevance of increasing volumes and improving the quality of agricultural products to ensure country food independence and increase participation in world food markets, pursuing a policy towards an effective employment structure will focus on sectors of the industry, by nature more than others predisposed to this. In modern Russian agriculture, such opportunities are more demonstrated by agricultural organizations and farms, as a rule, larger and more integrated in the areas of obtaining resources and selling their products. At the same time, the reduction and even the complete elimination of employment in other sectors is predetermined. The latter is most likely for consumer households, employment in some of which can be transformed predominantly into leisure activities, especially in the case of the development of alternative employment in the countryside, as well as an increase in pension provision. As the goal with agricultural production is achieved, the criteria basis for assessing the structure of agricultural employment will change. It will go beyond the boundaries not only of production, but also of solving the problems of employment and rural population income; it will expand due to the village non-agricultural functions, including such as preserving the natural environment, the human ecology, up to maintaining the nation gene pool, as evidenced by the experience of countries with resolved problems of food supply and decent income from employment.

V. Saraikin and co-authors give the following specific recommendations for improving agricultural structures [21]:

- the official approve the economic classes conditions of agricultural producers instead of the standard classification;

- adoption a methodology for agricultural structures distinguishing types, within the framework of which the roles of farm classes for each agricultural structure specific type will be determined;

- typing of agricultural structures at the regional and municipal levels;

- designing of agricultural policies and state support measures based on fundamentally new types of agricultural structures;

- redirection the state agrarian policy to create a competitive market for agricultural products and food, which could be easily accessed by small and medium actors, and create an inclusive and attractive service infrastructure for agriculture; 
- promotion in every possible way the cooperation and integration of family farms, the development of service infrastructure, including resellers and intermediaries;

- making an annual comparative analysis of agricultural structures, an annual assessment of the factors affecting their formation.

\section{CONCLUSION}

Cooperative scenarios for the reintegration of economic structures of the agrarian sector considering microregional, territorial and sectoral specifics are seen as the alternative directions for the further transformation of the agrarian structure of Russia. Project planning of large-size cooperative structures of the horizontal type (consumer cooperation networks), as well as stimulating the development of territorial cluster structures are considered to be the tools for these scenarios. The improvement of the agrarian structure in Russia is also possible by reducing the polarization in production of the marginal categories of extremely small and large-size agricultural producers by stimulating incentives for moving a significant part of production from the semi-subsistence production to the agricultural sector. Organizational and institutional changes in the agrarian policy should be implemented in the following areas: ensuring the equal access to the government support in order to increase the coverage of agricultural producers, modernization and contributing to the growth of seeds of agricultural development; simplification of the ways for granting and reducing the level of differentiation; restriction of the state support per organization, owner or affiliation in order to prevent overconcentration of production and capital; grant support to households for the creation of new industries in order to stimulate the transition to the level of tradable farm households.

The following measures should also be considered as additional measures for correcting the negative aspects of the transformation of the agrarian structure in the Russian Federation: the creation of a favorable institutional environment for the development of an independent farming sector; in-depth differentiation of the ways of the state support considering the ideology of economic classes of farms and microregional features; special measures for the development of territories with signs of agrarian decline; measures for territorial optimization of the agricultural production ratio considering non-economic factors (demographic, ethnic, religious); measures to expand non-agricultural functions of rural areas taking into account the specifics of the development of settlement networks of various regions of the federation.

\section{References}

[1] Land Reform: Defects in Agrarian Structure as Obstacles to Economic Development, New York: UN Department of Econ. Affairs, 1996.

[2] D. Walczak, M.B. Pietrzak, "Analysis of Agrarian Structure in Poland in 1921 and 2002 Based on the Example of Selected Districts", in M. Bilgin, H. Danis, E. Demir, U. Can (ed.), EBES 2014, vol. 1, pp. 461-472, 2016 [Business Challenges in the Changing Economic Landscape, Barcelona: Springer, Cham, 2016].
[3] P.I. Otiman, N. Mateoc-Sîrb, C. Mănescu, T. Mateoc, V. Goşa, A. Băneş, "A Study of Romania's Territorial Division and Regional Development", Revista de Cercetare si Interventie Sociala, no. 43, pp. 80-99, 2013.

[4] J. Möllers, J. Fritzsch, "Individual Farm Exit Decisions in Croatian Family Farms", Post-Communist Econ., vol. 22, no. 1, pp. 119-128, 2010.

[5] B. Grancelli, "Local Development in the Rural Regions of Eastern Europe: Post-Socialist Paradoxes of Economic and Socia Entrepreneurship", J. for East Europ. Manag. Stud., vol. 16, no. 1, pp. 34-39, 2011.

[6] B. Czyzewski, A. Matuszczak, "Towards Measuring Political Rents in Agriculture: Case Studies of Different Agrarian Structures in the EU", Agricult. Econ., vol. 64, no. 3, pp. 101-114, 2018.

[7] C. Oyvat, "Agrarian Structures, Urbanization, and Inequality", World Development, no. 83, pp. 207-230, 2016.

[8] B. Mickiewicz, A. Mickiewicz, "The Importance of Land Consolidation in Poland for the Processes of Shaping Agrarian Structure", in: A. Auzina (ed.), ESRD 2017, vol. 44, pp. 126-135, 2017 [Rural Development and Entrepreneurship Bioeconomy Production and CoOperation in Agriculture, Jelgava, 2017].

[9] C. Alexandri, L. Luca, "Implications of agrarian structures upon the agricultural supply in Romania", in: C. Luminita, C. Constantin I. Valeriu (eds.), ESPERA 2013, vol. 8, pp. 17-24, 2013 [Procedia Economics and Finance, Bucharest, 2013]

[10] J. Bozek, "Taxonomy of Agrarian Structure of Polish Subregions for Two Arrangements of Areal Classes of Farms", in: P. Jedlicka (ed.) Int. Sci. Conf. on Hradec Econ. Days 2013 - Economic Development and Management Region 2013, vol. 1, pp. 63-69, 2013, Hradec Kralove.

[11] A. Majchrzak, "Convergence Process of Agricultural Land Structures in the European Union", in: G. Mazure (ed.), Int. Sci. Conf. on Econ. Sci. for Rural Development, vol. 36, pp. 67-76, 2014 [Economic Science for Rural Development, Jelgava, 2014]

[12] V.Y. Uzun, N.I. Shagaida, "Evaluation of the Impact of Institutional and Structural Changes on the Development of the Russian Agricultural Sector", Voprosy Ekon., no. 4, pp. 39-58, 2019.

[13] V.A. Bogdanovsky, "Agrarian Structure as a Factor of Differences in Employment and Incomes", Agroprodovolstvennaya politika Rossii, vol. 11, no. 71, pp. 8-13, 2017.

[14] Development a Methodology and a Comparative Analysis of Agrarian Structures of Russia, the Russian Federation Subjects, and Foreign Countries: a Research Report. Moscow: VIAPI, 2012, 175 p.

[15] S.O. Siptits, E.A. Gataulina, "Influence of Factors on Formation of Agrarian Structure", Ekon. sel'skogo hoziaistva Rossii, no. 1, pp. 44-49, 2014

[16] E.A. Gataulina, "Comparative Analysis of the Agrarian Structures of Russia and the USA", Otechestvennye zapiski, vol. 6, no. 51, pp. 134-158, 2014

[17] V. Uzun, N. Shagaida, Z. Lerman, "Russian Agriculture: Growth and Institutional Challenges", Land Use Policy, no. 83, pp. 475-487, 2019.

[18] E.V. Ivanova, "Institutional Structure of the Agrarian Sector of the Russian Economy in the Context of the Implementation of the Food Import Substitution Policy", Rossiiskiy ekonomiceskiy internet-zhurnal, no. 3, 2017

[19] N.I. Shagaida, "Agrarian Structure as a Sustainability Factor of Agriculture", Srednerusskiy vestnik obschestvennykh nauk, vol. 12, no. 5, pp. 23-33, 2017.

[20] V.Y. Uzun, V.A. Saraikin, "Types of Institutional Agrarian Structures and their Zoning in Russia", Nikonovskie chtenia, no. 16, pp. 26-33, 2011.

[21] Improve the Agrarian Structure for the Effective Functioning of Sectors and Economic Forms of the Agro-Industrial Complex: a Research Report. Moscow: VIAPI, 2014, 105 p.

[22] I.M. Kulikov, "On the Rationalization of the Social Agrarian Structure: A View Through the Prism of Property Relations", Vest. Instit. Econ. RAN, no. 6, pp. 51-64, 2014. 